\title{
Youth Council Participation in Disaster Risk Reduction in Infanta and Makati, Philippines: A Policy Review
}

\author{
Glenn Fernandez* and Rajib Shaw \\ Graduate School of Global Environmental Studies, Kyoto University, Yoshida Honmachi, Sakyo-ku, Kyoto 606-8501, Japan
}

\begin{abstract}
Participatory disaster risk reduction (DRR) has been promoted to integrate the views of multiple actors and stakeholders and involve people in the decisions that affect their lives. Since 1974, a number of national policies in the Philippines have been encouraging the involvement of the Filipino youth in DRR initiatives in their communities. This study reviews the implementation of these policies through the Sangguniang Kabataan (youth councils) in Infanta Municipality and Makati City on the island of Luzon. It attempts to show the discrepancies between ideal scenarios reflected in the policies and actual youth council participation in DRR in practice by examining the availability of funds for youth councils to conduct DRR activities; the knowledge of youth council officials on the 2010 DRR law (Republic Act 10121); and the role of youth council officials in the Barangay (village level) DRR Committees. Several recommendations on how to enhance youth council participation in DRR are presented. Lessons from the Philippine policy experience can be useful for other countries in raising the involvement of their youth in DRR.
\end{abstract}

Keywords disaster risk reduction, Philippine policy, youth council, youth participation

\section{Introduction}

The Hyogo Framework for Action 2005-2015 promotes participatory disaster risk reduction (DRR) and states that "both communities and local authorities should be empowered to manage and reduce disaster risk by having access to the necessary information, resources, and authority to implement actions for disaster risk reduction" (UNISDR 2005, 5). By involving people in the decisions that affect their lives, participatory DRR has the potential to make initiatives more sustainable, integrative, and empowering (Cadag and Gaillard 2012).

In the Philippines, the necessity of participatory DRR is made more prominent by the need to develop and strengthen local disaster prevention, mitigation, response, and reconstruction capacities to complement national capacities. The

* Corresponding author. E-mail: glenn.fernandez.62u@

st.kyoto-u.ac.jp
Philippines is one of the world's most disaster-prone countries (IFRC 2009) and has been consistently among the top five countries with the highest number of reported disaster events in the last six years (CRED 2013). The country is exposed to almost all types of natural hazards because of its geographical location in the Pacific Ring of Fire and along the typhoon belt. Contributing to disaster risk is the high level of vulnerability among the population; more than a quarter are considered poor (NSCB 2013).

Participatory DRR is meant to integrate the views of multiple actors and stakeholders (Pelling 2007), including the national government, local governments, national and international NGOs, UN agencies, academia, mass media, business sector, faith-based organizations, and communitybased organizations. One way to view participation is in terms of the scope, such as the number of participants and the frequency and duration of activities, although these are not an adequate measure of quality participation (Checkoway 1998). Participation is considered effective if it shows some effect, influences a particular decision, or produces a favorable outcome, which can occur at the individual, organizational, or community levels.

This article examines the participation in DRR of the Filipino youth, one of the "vulnerable and marginalized groups," as defined in the Implementing Rules and Regulations of the Philippine Disaster Risk Reduction and Management Act of 2010 (NDRRMC 2010). For statistical purposes such as cross-country comparisons the United Nations defines "youth" as persons between the ages of 15 and 24 years. Each country sets its own youth age range. For example, youth in Southeast Asia can be as young as 12 in Timor Leste and can be as old as 40 in Brunei Darussalam and Malaysia (Fernandez 2012). In the case of the Philippines, the youth are persons from 15 to 30 and would normally include fourth-year junior high school students and older, college students, those who are already working, and even married individuals.

The objectives of this article are to summarize the policies at the national level related to youth participation in DRR and to review the implementation of these policies at the barangay (village) level through youth councils, citing reports produced by and for the National Youth Commission 
and field observations of the authors gathered from 2010 to 2013. We aim to show the discrepancies between ideal scenarios and actual youth participation in DRR in practice. The following questions are addressed: (1) why should young people be involved in DRR; (2) what existing national policies in the Philippines mention the roles of the youth in DRR and how are these roles promoted by the government; (3) what resources and opportunities at the local level are available for the implementation of these policies; (4) to what extent have the policies reached their objectives; and (5) what can be done to further enhance youth participation in DRR?

Findings are expected to fill a major gap in existing knowledge about youth participation in DRR and provide the muchneeded evidence base for the formulation and implementation of future policies to enable and improve youth participation in DRR. Research that sheds light on the extent to which young people participate in DRR and the factors that facilitate or inhibit their involvement is currently sparse, not only in the Philippines but in other countries as well (Fernandez 2012).

\section{Rationale for Youth Participation in DRR}

It is widely accepted that there is added value in working with young people. In general, there are three main rationales for greater voice and participation of the youth (Head 2011). First, it is argued that young people have the right to be nurtured, protected, and treated with respect, and, where appropriate, be consulted and involved. Second, it is recognized that the improvement of services for young people requires their views and interests to be well articulated and represented. And third, it is asserted that there are developmental benefits from youth participation, for both the young people themselves and for society as a whole. Participation of young people can promote their personal development; strengthen their knowledge, practical skills, social values, and civic competencies; and prepare them for their roles as adult citizens (Checkoway, Allison, and Montoya 2005; Timmerman 2009; Checkoway 2011).

The international DRR community has been advocating a participatory approach, but young people continue to be left out. The youth are among the marginalized segments of societies that bear the brunt of disasters (Gaillard and Pangilinan 2010). There is a growing literature stressing the impact of natural hazards on the youth and the importance of assigning them a role in disaster risk reduction. Although young people are vulnerable to disasters and need to rely on adults for various forms of protection and support, they nevertheless possess significant qualities that could serve as an important resource for households and communities in preparing for, responding to, and recovering from disasters. Their knowledge, creativity, energy, enthusiasm, and social networks could be used in different phases of DRR to help themselves and others (Peek 2008). Table 1 shows several actual examples of youth activities collected from DRR-related projects of the Ten Accomplished Youth Organizations (TAYO) Award winners and finalists as well as from activities of Red Cross Youth (Philippines), Boy Scouts of the Philippines, Girl Scouts of the Philippines, and Philippine Society of Youth Science Clubs.

Excluding the youth from DRR processes threatens their safety from disasters and neglects a valuable resource for risk communication, education, advocacy, and action-oriented risk reduction activities (Anderson 2005). The evidence confirming the value of young people's participation in DRR is getting stronger (Walden, Hawrylyshyn, and Hall 2009). For example, the experiences of an international NGO working with youth in the Philippines on community risk mapping and mitigation activities have shown that the youth have a much greater capacity to participate in DRR than many people assume (Mitchell, Tanner, and Haynes 2009). These young people used their DRR knowledge to successfully persuade school officials and community planners to relocate their school, previously situated in a high-risk landslide zone, to a safer area. Young people can offer innovative ideas about managing risks, provided they are encouraged to learn about disasters, hazards, vulnerability, and coping capacities (Walden, Hawrylyshyn, and Hall 2009). They also have the ability to share and apply what they learned within their households, families, and the wider community (Shaw et al. 2009). The youth should be regarded as potential partners in conducting DRR activities (Fernandez 2012).

Table 1. Young people's contributions in different phases of disaster risk reduction (DRR)

\begin{tabular}{|c|c|c|}
\hline Preparedness & Response & Recovery \\
\hline $\begin{array}{l}\text { Canal de-clogging and dredging projects to avert the } \\
\text { perilous effects of flash floods }\end{array}$ & $\begin{array}{l}\text { Providing emergency medical services to } \\
\text { disaster victims }\end{array}$ & $\begin{array}{l}\text { Planting various high-yielding fruit trees on a } \\
\text { denuded mountain after a devastating flash }\end{array}$ \\
\hline Fund-raising for acquiring necessary life-saving gear & Helping in relief operations (distributing & flood \\
\hline and vehicles & food, clothes, and medicines to families & Acknowledging the contribution of those who \\
\hline Conducting first-aid, cardiopulmonary resuscitation (CPR), & in evacuation centers) & helped in emergency response and recovery \\
\hline and water safety trainings as well as fire and earthquake drills & Joining search, rescue, and retrieval & efforts \\
\hline Supporting the campaign on voluntary blood donation & operations & Reviewing and modifying preparedness plans \\
\hline $\begin{array}{l}\text { Risk communication through community mapping } \\
\text { (identifying hazardous areas, safe areas, and evacuation routes) }\end{array}$ & $\begin{array}{l}\text { Operating a 24-hour disaster and } \\
\text { emergency response organization }\end{array}$ & $\begin{array}{l}\text { Volunteering to build houses for poor disaster } \\
\text { victims }\end{array}$ \\
\hline
\end{tabular}

Source: Compiled from Fernandez (2012). 
International campaigns have called for the participation of the youth in DRR. The theme of the first campaign of the United Nations International Strategy for Disaster Reduction (UNISDR) after it was established in 2000 was "Disaster Prevention, Education, and Youth," acknowledging that young people represent powerful forces for change and for mobilization. The youth can promote the necessary change in behaviors and a shift in mentalities, which are needed in successful disaster prevention and risk management (UNISDR 2000). Young people should be given the chance to ensure their own protection and the protection of their world, through appropriate education and level of responsibility in the decision-making process. Participation was also a theme of the first and second International Year of Youth in 1985 and 2010. Unfortunately, disaster risk reduction is not among the priority areas enumerated in the World Program of Action for Youth (UN 2010a).

At the operational level, participation is about information sharing, consultation, decision making, and initiating action (SPW and DFID 2010). Participation makes social relationships possible, thereby preventing marginalization and facilitating social cohesion (Timmerman 2009). Participatory processes can build social capital over the longer term and deliver more sustainable solutions (Lyons, Schilderman, and Boano 2010). Preventing young people's marginalization and leveraging their capacity to help build social capital are compelling reasons why they should be involved, not just in DRR but in general.

\section{Philippine Policies on Youth Participation in DRR}

In the Philippines, youth between the ages of 15 and 24 are estimated at 18.7 million and comprise one-fifth of the total population (UN 2010b). Filipino young people hold great promise in addressing important issues like DRR because of their energy, passion, and number. Over the years, several national policies in the form of laws, resolutions, and plans have pushed for the inclusion of young Filipinos in DRR efforts (Table 2). In examining these national policies formulated from 1974 to 2013, there is a noticeable shift from the view of youth as disaster victims and beneficiaries of relief aid and protection to the view of youth as resources, actors, and partners. The government has increasingly seen young people as competent citizens with a right to participate and a responsibility to serve their communities. According to Checkoway (1998), proponents of this view want the youth to build on their strengths by "making a difference" in ways that provide them with tangible benefits and allow them to help develop healthier communities.

Even before it became a signatory to the UN Convention on the Rights of the Child, the Philippines had already enacted a law to ensure that the voices of children and young people were heard on issues that directly concerned them. As early as 1974, when Presidential Decree 603 was signed into law, the youth were already given the responsibility to "participate actively in civic affairs and in the promotion of the general welfare, always bearing in mind that it is the youth who will eventually be called upon to discharge the responsibility of leadership in shaping the nation's future." This view of encouraging youth involvement in public and civic affairs was echoed in the 1987 Constitution of the Philippines.

In 1991, Republic Act 7160, also known as the Local Government Code, formed the Katipunan ng Kabataan (KK, youth federation) "to tap and harness the energy, enthusiasm, and idealism of young people." Those aged 15 to below 18 years old in a barangay could register in the KK and have the right to vote and be voted into a governing body called the Sangguniang Kabataan (SK, youth council). The SK is allocated 10 percent of the annual budget of the barangay. The SK chairperson assumes a seat in the Barangay Council (BC) and is given full powers and authority like any of the adult members of the BC. There are SK federations at the municipal, city, provincial, and national levels. For example, at the municipal level, all SK chairpersons belonging to one municipality will elect from among themselves an SK Municipal Federation President. The elected federation president will then serve as an ex-officio youth member of the municipal council, again given full powers like the other adult municipal councilors.

This pioneering effort sets the Philippines apart in the area of youth involvement in local governance. The setup allows the Filipino youth to acquire leadership skills by actually becoming leaders: learning how to speak and be heard in the world of adults and be empowered to create programs and policies that will help solve society's problems (Balanon et al. 2007). So far, the Philippines is the only country in the world to have this kind of grassroots-based, government-funded political structure for young people (Balanon et al. 2007). Because of this, the SK is considered a quintessential example of youth participation in local governance. It is a testament to the Philippine Government's recognition of the potential of the youth to contribute to national development.

\section{Implementation of Policies on Youth Participation in DRR by Youth Councils}

To review the implementation of these national policies at the village level, a questionnaire survey and interviews were conducted in Makati City, Metro Manila and Infanta Municipality, Quezon Province, both located on Luzon Island in the Philippines, from July to August 2012. Semi-urban Infanta is $143 \mathrm{~km}$ from Manila City, the country's capital, while highly urbanized Makati shares its northwest border with Manila (Figure 1). The population of Infanta was 64,866 in 2010. Being the financial center of the Philippines, Makati's daytime population can reach up to 3.7 million; however its nighttime population was only 529,039 in 2010. In 2012 Makati and Infanta signed a twinning agreement, with the aim of strengthening ties of friendship and mutual understanding 
Table 2. National policies in the Philippines related to youth participation in disaster risk reduction (DRR)

\begin{tabular}{|c|c|c|}
\hline Year & Policy & Salient Points \\
\hline 1974 & $\begin{array}{l}\text { Presidential Decree } 603 \\
\text { The Children and Youth } \\
\text { Welfare Code }\end{array}$ & $\begin{array}{l}\text { In case of earthquake, flood, storm, conflagration, epidemic, or other calamity, the State shall give special } \\
\text { assistance to children and youth whenever necessary. } \\
\text { On occasions of national or local disasters the school may accept voluntary contributions or aid from students for } \\
\text { distribution to victims of such disasters or calamities. }\end{array}$ \\
\hline 1987 & $\begin{array}{l}1987 \text { Constitution of the } \\
\text { Republic of the Philippines }\end{array}$ & $\begin{array}{l}\text { The State recognizes the vital role of the youth in nation-building and shall promote and protect their physical, } \\
\text { moral, spiritual, intellectual, and social well-being. It shall encourage their involvement in public and civic affairs. }\end{array}$ \\
\hline 1991 & $\begin{array}{l}\text { Republic Act } 7160 \\
\text { The Local Government } \\
\text { Code }\end{array}$ & $\begin{array}{l}\text { This law created the Katipunan ng Kabataan (KK, youth federation) and the Sangguniang Kabataan (SK, youth } \\
\text { council) at the barangay (village) level, as well as the SK Federation at municipal, city, provincial, and national } \\
\text { levels. } \\
\text { Each SK receives a } 10 \text { percent share of the barangay fund for its projects. } \\
\text { The SK shall create such bodies or committees as it may deem necessary to effectively carry out its programs and } \\
\text { activities. }\end{array}$ \\
\hline 1995 & $\begin{array}{l}\text { Republic Act } 8044 \\
\text { The Youth in } \\
\text { Nation-Building Act }\end{array}$ & $\begin{array}{l}\text { Defines "youth" as persons from } 15 \text { to } 30 \text { years old. } \\
\text { This law created the National Youth Commission (NYC) and constituted the National Youth Parliament (NYP). } \\
\text { The functions of NYC include the allocation of resources for the implementation of youth programs and projects } \\
\text { and the provision of training and a national secretariat for the SK National Federation. }\end{array}$ \\
\hline 2001 & $\begin{array}{l}2011 \text { SK Constitution and } \\
\text { By-Laws }\end{array}$ & $\begin{array}{l}\text { Fifty-eight percent of its total annual fund shall be allocated by the SK for various concerns, such as Disaster } \\
\text { Coordination and Calamity Management. } \\
\text { There shall be in every barangay-level SK a Disaster Coordination and Health Task Force to be headed by the } \\
\text { third-ranking SK Councilor and shall have a membership of } 20 \text { percent of the KK members. }\end{array}$ \\
\hline 2005 & $\begin{array}{l}\text { Medium Term Youth } \\
\text { Development Plan } \\
\text { (MTYDP) 2005-2010 }\end{array}$ & $\begin{array}{l}\text { MTYDP encouraged youth membership in Barangay Disaster Coordinating Councils. } \\
\text { MTYDP encouraged the promulgation of laws to include the youth in first aid, mass evacuation, and disaster } \\
\text { management operations. }\end{array}$ \\
\hline 2009 & $\begin{array}{l}\text { Republic Act } 9729 \\
\text { Climate Change Act }\end{array}$ & $\begin{array}{l}\text { The Department of Education (DepED) shall integrate climate change into the primary and secondary education } \\
\text { curricula and/or subjects, such as, but not limited to, science, biology, civics, history, including textbooks, primers } \\
\text { and other educational materials, basic climate change principles and concepts. }\end{array}$ \\
\hline 2010 & $\begin{array}{l}\text { Republic Act } 10121 \\
\text { Disaster Risk Reduction } \\
\text { and Management Act }\end{array}$ & $\begin{array}{l}\text { This law called for the integration of DRR education in the school curricula of secondary and tertiary level of } \\
\text { education. } \\
\text { The national and local DRR councils, the Barangay DRR Committees, and the SK councils shall encourage } \\
\text { communities, specifically the youth, to participate in DRR activities. }\end{array}$ \\
\hline 2012 & $\begin{array}{l}\text { Resolution } 09-12-03 \text { of the } \\
\text { 9th National Youth } \\
\text { Parliament }\end{array}$ & $\begin{array}{l}\text { This resolution called for the enhancement of the participation of the youth sector in the planning, information } \\
\text { dissemination, implementation, and monitoring of the disaster risk reduction management plans of local } \\
\text { government units. }\end{array}$ \\
\hline 2013 & $\begin{array}{l}\text { Philippine Youth Develop- } \\
\text { ment Plan (PYDP) 2012- } \\
2016 \text { (under preparation) }\end{array}$ & $\begin{array}{l}\text { PYDP calls for increased youth participation in local DRR councils. } \\
\text { PYDP promotes youth volunteerism in the implementation and monitoring of disaster preparedness and other } \\
\text { major programs where youth participation can make a substantial contribution. } \\
\text { PYDP encourages the mobilization and deployment of youth volunteers during disasters and other emergencies. }\end{array}$ \\
\hline
\end{tabular}

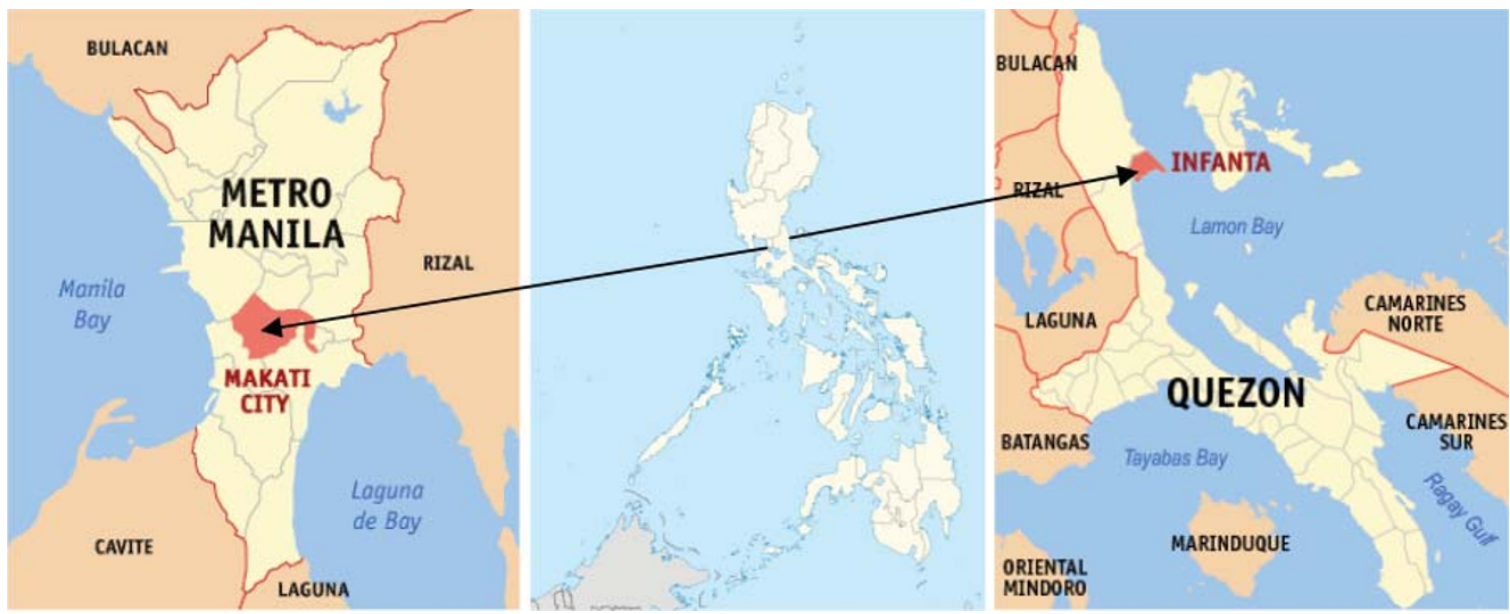

Figure 1. Location of the study areas in the Philippines

Source: Maps from Wikipedia Commons. 
through exchanges in science and technology, culture and arts, tourism, planning and urban development, environmental protection, public health and social services, and other common concerns (Infanta Municipal Government 2012).

Both Infanta and Makati are prone to hazards like typhoons, floods, landslides, and earthquakes. As a coastal town, Infanta is also affected by storm surges and tsunamis. In the field of DRR, both Makati and Infanta are awardwinning local government units. In 2012, Makati was granted the Hall of Fame award by the National Disaster Risk Reduction and Management Council (NDRRMC) for winning the Gawad KALASAG (Search for Excellence in DRR) award at the national level for three consecutive years, from 2010 to 2012 (Paunan 2012). In 2007, Infanta received a Galing Pook (Outstanding Local Governance Program) award for its community preparedness program (Galing Pook Foundation 2007).

This study is the first to examine critically the extent of youth participation in the DRR initiatives of the two local government units as well as investigate the youth councils' own DRR activities. In the questionnaire survey, the SK chairs (or his or her representative) were asked to answer questions regarding their participation in National Disaster Consciousness Month (NDCM) activities and their knowledge of Republic Act 10121. They were also requested to provide a copy of their Barangay Disaster Risk Reduction and Management Committee (BDRRMC) Organization Chart to determine if the SKs are given formal roles in the committee. Lastly, they were asked to provide a copy of their SK Annual Budget to find out if the expenditures of the SK are in line with the provisions on spending allocations in the by-laws.

After the questionnaires were received, each barangay was visited by the researcher in the company of a local assistant (in the case of Infanta) or at least three local assistants (in the case of Makati). Clarifications related to replies to the questionnaire were made. The Barangay Council and
SK officials were also asked about their past, present, and future DRR initiatives for the youth; about how they communicate to the youth in the village; about their resources for DRR programs; about major challenges in involving young people in DRR; about partnerships with other DRR actors and stakeholders; and so on.

\subsection{Funds of Youth Councils for DRR Activities}

Though the SK has been touted as a landmark institution that promotes the engagement of the youth in governance, the SK's performance for the past 10 years has been generally weak, especially in following the required budget allocations mandated by the 2001 SK Constitution and By-Laws (UNICEF EAPRO 2008). For example, Table 3 shows the prescribed budget allocations based on the SK Constitution and the actual allocations made by 17 SKs in Infanta and 18 SKs in Makati. In Infanta, none of the SKs invested in DRR projects, like preparedness training for young people and relief operations and psychosocial services for youth during disasters. The SK councils spent their funds mostly on sports-related projects like construction and maintenance of basketball courts and organizing basketball tournaments. They also spent substantial amounts on annual beauty pageants. Projects that address the important problems facing the youth, such as livelihood, were lacking. Projects on education and training, health and nutrition, and environmental protection were hardly mentioned.

In Makati, a resolution was adopted by the SK Federation to require each SK to allot five percent of its annual budget for the SK's DRR program (Makati SK Federation 2013). Most of the DRR activities of the youth councils are trainings on how to provide emergency first aid and on how to become volunteers in their barangay. A few SKs also conduct seminars for the youth on disaster preparedness, evacuation, and

Table 3. Percentage of prescribed vs. actual spending of Sangguniang Kabataan (SKs; youth councils) in Infanta and Makati, Philippines

\begin{tabular}{|c|c|c|c|}
\hline Activities & $\begin{array}{c}\text { Prescribed Allocation } \\
\text { (\%) }\end{array}$ & $\begin{array}{l}\text { Actual Allocation in Infanta } \\
\qquad(2012, n=17)(\%)\end{array}$ & $\begin{array}{l}\text { Actual Allocation in Makati } \\
\qquad(2013, n=18)(\%)\end{array}$ \\
\hline Environmental Projects / Green Brigade & 10 & 4 & 11 \\
\hline Livelihood Projects & 10 & 0 & 10 \\
\hline Capability Building & 10 & 10 & 6 \\
\hline Anti-Drug Abuse Campaign & 10 & 0 & 11 \\
\hline Education Services and Moral Recovery Program & & 5 & 21 \\
\hline Health Services and Adolescent Reproductive Health Program & & 6 & 3 \\
\hline Disaster Coordination and Calamity Management & & 0 & 4 \\
\hline Sports Development Activities & & 37 & 24 \\
\hline Community Immersion & 58 & 0 & 3 \\
\hline Infrastructure Projects & & 14 & 0 \\
\hline Legislative Work and Involvement & & 0 & 2 \\
\hline Other Development Programs Vital for the Youth & & 23 & 3 \\
\hline Annual Dues to SK Federations & 2 & 0 & 2 \\
\hline TOTAL & 100 & 100 & 100 \\
\hline
\end{tabular}

Source: Computed by the authors based on SK budgets provided by Infanta and Makati. 
vulnerability analysis, as well as distribute emergency first aid kits.

On average, the total annual budget of SKs in Infanta is USD 2,400 while for the SKs in Makati it is USD 74,500, reflecting a sharp contrast between the SKs in a rural municipality and the SKs in the country's financial capital. In Makati, the annual budget for youth council DRR activities is around USD 3,200 per village.

\subsection{Knowledge of Youth Council Officials of the 2010 DRR Law}

In 2010 the Philippines Disaster Risk Reduction and Management Act (Republic Act 10121) was enacted. This law provides for the development of policies and plans and the implementation of actions and measures pertaining to all aspects of disaster risk reduction and management, including good governance, risk assessment and early warning, knowledge building and awareness raising, reducing underlying risk factors, and preparedness for effective response and early recovery.

Table 4 shows the results of a survey in July-August 2012 on how much youth council officials know about the basic salient points of the disaster law two years after it was signed by the President. For five out of nine questions, most of the youth council officials gave the wrong answer. With the exception of one question, significantly more SK officials in Makati know the correct answers compared to their counterparts in Infanta.

Poor knowledge of the 2010 DRR law might be an indication of young people's low level of participation in DRR activities. Good knowledge of the DRR law could have prompted the youth councils to proactively ask for a task in the DRR committee. One of the possible reasons why the youth councils did not allocate funds for DRR is that they are not aware of their need to participate. The high number of respondents who answered incorrectly basic questions about the DRR law highlights the need for more DRR education at the village level, which is the "frontline" where disasters really take place.
Republic Act 10121 and the related Republic Act 9729 (Climate Change Act of 2009) call for the integration of DRR and climate change adaptation (CCA) education in school curricula, textbooks, and teachers' guides and manuals, targeting 30 percent implementation by 2013 (NDRRMC 2011). Implementation might be affected by the introduction of the K-to-12 Basic Education Program started in 2011, which added two more years of basic education to the previous education program. The K-to-12 Basic Education Program has impacts on the development or adjustment of curriculum materials. The first author visited the libraries of five high schools in Quezon City in September 2011 and five bookstores in Metro Manila in August 2012 but could not find any new book that included CCA and DRR concepts or highlighted recent legislation. This might help explain the low level of knowledge of the mostly student youth council officials.

\subsection{Role of the Youth Council Officials in the Barangay DRR Committees}

Since disasters can affect everyone, DRR should be everybody's concern, including the youth. In a significant departure from the old disaster management law, Presidential Decree 1566 of 1978 (Strengthening the Philippine Disaster Control Capability and Establishing the National Program on Community Disaster Preparedness), Republic Act 10121 (Philippine Disaster Risk Reduction and Management Act of 2010) specifically mentions the importance of youth participation in DRR. However, so far very little has been done to involve the youth in DRR, whether in the community or in school (Fernandez 2012). Most of the DRR activities conducted by the youth have been autonomous (per school, per barangay, or per local government unit only) and not coordinated. There has been no evaluation on the impact of these activities. Documentation of the number of participants, number of projects conducted, cost of the projects, support from adults, and so on has also been poor.

The implementing rules and regulations of Republic Act 10121 do not elaborate on the specific roles and tasks of the

Table 4. Percentage of youth council officials who answered correctly to questions related to the 2010 disaster risk reduction (DRR) Law in the Philippines

\begin{tabular}{lc}
\hline Questions & Infanta (n=18) (\%) \\
\hline Who is the head of the National DRR Council & 17 \\
Who is the head of the Regional DRR Council & 11 \\
How many hours is the National DRR Operations Center open daily & 72 \\
How many civil society organization / nongovernmental organization representatives should & 22 \\
be in the Barangay DRR Committee & 33 \\
If only one village is affected, who should lead the emergency response & 22 \\
Can relief goods be bought from intended recipients & 73 \\
How much of the Barangay DRR Fund should be set aside as Quick Response Fund & 33 \\
Who was the President who signed the Disaster Law & 67 \\
Is youth participation in DRR activities encouraged by the Disaster Law & 50 \\
\hline
\end{tabular}

Source: Questionnaire survey conducted by the authors. 
youth on DRR in their barangay. In the survey conducted by the authors in July and August 2012 among SK officials in the 36 villages of Infanta and 33 villages of Makati, very few SK officials had a clear understanding of what is expected of them, causing them not to plan and budget for DRR activities (see Table 3). Although Republic Act 10121 also calls on the national and local DRR councils, the Barangay Disaster Risk Reduction and Management Committees (BDRRMCs), and the SKs to encourage youth participation in DRR activities, analysis of the composition of the BDRRMCs reveals that only nine out of 22 villages of Makati City that provided a copy of their BDRRMC organization chart have youth members (Table 5). The average age of the members of the BDRRMCs is well above the Philippine youth age range from 15 to 30. For example, the average age in Barangay A is 45, in Barangay $\mathrm{D}$ is 48 , and in Barangay $\mathrm{F}$ is 44 .

The Medium Term Youth Development Plan 2005-2010 (MTYDP) encouraged youth membership in Barangay Disaster Coordinating Councils (BDCCs, the predecessors of the BDRRMCs) and the promulgation of laws to include the youth in first aid, mass evacuation, and disaster management operations (NYC 2005). However, there has been no formal study on the age of the members who comprised the BDCCs.

The preparation of the Philippine Youth Development Plan 2012-2016 (PYDP) has been delayed, creating a long gap between the 2005 MTYDP and the PYPD. Based on the advance copy of the PYDP provided by the National Youth Commission (NYC) to the authors, the new PYPD will call for increased youth participation in local DRR councils. It will also promote youth volunteerism in the implementation and monitoring of disaster preparedness and other major programs where youth participation can make a substantial contribution. In addition, the PYPD will encourage the mobilization and deployment of youth volunteers during disasters and other emergencies. According to the PYPD advance copy, "the state shall create opportunities to involve and assist the youth in various development programs." One of the identified programs and other opportunities where such productive partnership can be developed is labeled "Youth, climate change, and the environment," which includes youth participation in DRR.
In its 2011 accomplishment report, the NYC mentioned that one of its firm advocacies in the medium term is its National Youth Disaster Response Program (NYC 2012). The government would like the youth to take an active role in disaster preparedness through capacity building, to prepare themselves for times of natural disasters. Through the National Youth Disaster Response Program, the youth will be provided with the proper knowledge and skills in responding to disasters. The NYC did not elaborate on why it chose to focus on disaster response, instead of disaster preparedness. The program was not adopted for inclusion in the President's State of the Nation Address when it was proposed as a policy statement by the NYC (NYC 2012).

During the 2012 National Youth Parliament (NYP), a three-day convention of youth leaders from all over the country organized by the NYC and held every two years, one of the resolutions adopted (Resolution 09-12-03) calls for the enhancement of the participation of the youth sector in the planning, information dissemination, implementation, and monitoring of the disaster risk reduction and management plans of local government units. No details are provided on how this resolution will be executed. But according to the PYDP, to integrate the youth agenda in national and local development plans, NYP resolutions will be addressed by national government agencies (NGAs), local government units (LGUs), and Congress in 2012-2016. The PYDP also did not elaborate on the integration process.

Among Asian countries, the Philippines is considered relatively advanced in terms of legislation related to various challenging issues such as DRR and CCA. During her visit to the Philippines in May 2012, Margareta Wahlström, special DRR representative of UN Secretary-General Ban Ki-moon, remarked that the country's laws on DRR and CCA are the "best in the world" (Ubac 2012). Senator Loren Legarda, the UN Champion for DRR and CCA for Asia and the Pacific, thanked Wahlström for the compliment but said that the "challenge is to translate them into local community action to save lives and reduce disaster risks and economic losses" (Ubac 2012). Strietska-Ilina et al. (2011) had commented that there is a wide gap between the enactment of laws and the enforcement of laws in the Philippines. Although on paper the youth

Table 5. Composition of the Barangay Disaster Risk Reduction and Management Committees (BDRRMCs) in Makati City, Quezon Province, Philippines and the roles assigned to youth members

\begin{tabular}{lccl}
\hline Barangay (Village) & Number of Members & Number of Youth Members & Role Assigned to Youth Members \\
\hline A & 68 & 2 & Vice Chairperson; medical service \\
B & Not provided & At least 7 & Emergency response (all SK officials are committee heads and members) \\
C & 11 (officers only) & 1 & Relief \\
D & 23 & 1 & Vice Chairperson \\
E & 13 (officers only) & 1 & Warning service leader \\
F & 13 (officers only) & 0 & Evacuation (SK officials are committee members) \\
G & 12 (officers only) & 2 & Damage control; search and rescue \\
H & 162 & At least 7 & Relief (all SK officials are committee heads and members) \\
I & 32 & 1 & Evacuation \\
\hline
\end{tabular}

Source: Questionnaire survey conducted by the authors (actual names of barangay omitted to provide anonymity). 
are encouraged to participate in DRR, the actual participation of the youth in local DRR undertakings is low. Despite the increased policy commitments to youth participation in general, there is confusion about the operational implications of such commitments (Head 2011). Implementation has therefore remained patchy.

\section{Recommendations for Enhancing Youth Participation in DRR}

The reports and observations on the availability and the status of implementation of national policies related to youth council participation in DRR in the Philippines are used as bases for recommendations for improving how young Filipinos can be involved in building disaster resilience and promoting a culture of safety in their barangay or community.

\subsection{Involving the Youth at the National Level}

In terms of participation of stakeholders, Republic Act 10121 expanded the membership of the NDRRMC from the former NDCC setup which was mainly composed of the government's line departments. The NDRRMC is now composed of a Chairperson, four Vice-Chairpersons, and 39 members including representatives of four civil society organizations (CSOs) and one from the private sector. The Chairperson of the National Youth Commission (as the main youth agency and as secretariat of the SK National Federation) should be included as member of the NDRRMC, in the same way that the President of the Liga ng Mga Barangay (LMB, League of Villages), the adult counterpart of the SK National Federation, and representatives of CSOs and the private sector are included. The Filipino youth (or their representatives) are still largely excluded from important tasks, like formal planning and decision making. Disaster risk reduction is dominated by top-down relief efforts that assume the youth are passive victims with no role in preventing, mitigating, and responding to disasters (Mitchell et al. 2008). The membership of the NYC in the NDRRMC will send a strong signal that the youth, which represent a large pool of volunteers, is being taken seriously and recognized as a major partner in DRR. One of the lessons learned in a review of the national youth policy in the Philippines is that there should be support for youth involvement at a high level (Carey 2011).

As local-level implementation of national policies frequently follows the national-level model, the inclusion of the NYC in the NDRRMC might encourage the inclusion of the SKs in the BDRRMCs. If the youth have no participation at the national level, then this might send a message to the local level that youth participation is not required or is unimportant.

\subsection{Participating in Annual DRR Activities}

The youth should be urged to actively participate in annual DRR activities, like the National Disaster Consciousness
Month (July) celebration, the Fire Prevention Month (March) celebration, the International Day for Disaster Reduction (October 13), and so on. The youth should also conduct DRR activities during the annual Linggo ng Kabataan (Youth Week) celebration every second week of December. Memoranda or advisories should be issued by the appropriate government agencies to remind in-school youth, out-of-school youth, working youth, and youth with special needs to take part in DRR activities, taking into consideration that it has been observed that most citizens are either uninvolved or minimally involved in community affairs while only a very small group of people is extremely active (Checkoway 2011).

At the barangay level, there are several tasks to choose from, like helping maintain the evacuation shelter, putting up warning signs, organizing emergency drills, preparing relief goods, and so on. Youth council officials can volunteer to assist in information dissemination through the use of social media, like Facebook, Twitter, and YouTube, as they are generally more technology savvy than older people.

The youth themselves must also be consulted on how and when they can get involved in DRR activities, taking into consideration their priorities and time available. An array of school-based and community-based DRR activities should be organized to provide young people with ample choices depending on their availability and interest and on the costs and logistics involved. But in planning and implementing DRR activities, organizers must see to it that the participation by young people is meaningful (Carey 2011) and leads to favorable outcomes.

\subsection{Looking into the Roles of Other Youth Organizations}

Aside from the SKs, the government should also look into the possible roles of other youth organizations. There are many existing youth organizations in the country that can be vehicles for youth participation in DRR: Red Cross Youth (RCY), Boy Scouts of the Philippines (BSP), Girl Scouts of the Philippines (GSP), Youth for the Environment in Schools Organization (YES-O), Philippine Society of Youth Science Clubs (PSYSC), student councils, and so on. For example, in 2010 the PSYSC organized a disaster preparedness-themed, four-day summer camp. More than 900 high school students and teachers, representing science clubs from all over the country, participated. Lectures included (1) Science of Disasters and Detection of Hazards (explanation on the different kinds of geological and hydrometeorological hazards, recent major disasters in the Philippines, and advances in Doppler radar and seismograph technology and other ways of knowing when a disaster is impending); (2) Community in Action: From Tragedy to Strategy (impact of disasters on national development; community-based disaster risk management); and (3) Disaster Preparedness 101 (4 Rs of Disaster Management: Reduction, Readiness, Response, Recovery; thinking globally, acting locally-what science clubs can do to help in 
building the disaster resilience of their communities). A venue for high school students and teachers was provided to meet real scientists and experts in the field of disaster management, like the Director of the Philippine Institute of Volcanology and Seismology (PHIVOLCS) and the Chief of the Weather Division of the Philippine Atmospheric, Geophysical and Astronomical Services Administration (PAGASA). Advocating fun experiential learning, the PSYSC created a venue that allowed scientists to interact directly with students, enabling them to make valuable contributions like modeling scientific inquiry, sharing their passion for science, connecting science and technology to the "real" world, and augmenting the science background of the teachers and students.

Table 6 summarizes the timing and nature of the DRR activities conducted by various youth organizations in the Philippines. In the 2010 National Youth Assessment, about one-third of the youth surveyed said that they would volunteer in community service in times of emergency (NYC 2010).

The NYC and NDRRMC should address the lack of communication and coordination among youth organizations that lead them to conduct autonomous DRR activities with limited impact and on a limited scope only. Synergies in terms of the timing and nature of the activities of the different youth organizations can be taken advantage of.

\subsection{Compiling Data on Youth Participation}

Reliable data on youth participation in DRR in the Philippines should be compiled and reported. Lack of reliable data is a major constraint in understanding what needs to be done and how it can be done effectively. As Twigg (2009) remarked, replicability, along with sustainability, is considered one of the main challenges to making community-based DRR effective. Unless good practices in youth participation in DRR are shared, the spread of these practices can be slow, inefficient, and costly, as individuals and groups have to experiment to find out for themselves what works and what does not. With replicable models, there is the advantage of being able to learn from other people's mistakes and by-pass the normally long learning process and go directly to adopting and implementing practices that have been proven effective in other locations. One glaring finding in a study of SK accomplishments is that SK councils do not submit reports, or these reports fail to reach the NYC (Balanon et al. 2007). This is one issue that the NYC can look into that has the potential to be addressed quickly at no high cost.

Even though DRR practitioners know why they should involve the youth, they do not always know how to do it. This is not only because the task is inherently difficult but also because there is not enough precedent guidance and practical understanding. User-friendly recommendations, guidance, and tools on how to institutionalize and mainstream youth participation in risk assessments, implementation of early warning systems, preparedness activities, and usage of indicators to monitor the progress of youth participation should be produced by the NYC and NDRRMC in order to increase the voice of young people and the visibility of their roles in and contributions to DRR. A repository of good practices in youth participation in DRR should be set up and then promoted across the country and beyond.

\subsection{Ensuring the Safety of Young People Involved in DRR Activities}

Safety should be observed in conducting DRR activities involving young people. Because the youth do not perform at the same levels as adults, it is important that programs that target the youth population are developed and that these

Table 6. Different youth organizations' disaster risk reduction (DRR) activities in the Philippines

\begin{tabular}{|c|c|c|c|}
\hline Youth Organization & Number of Local Chapters & Occasions for DRR Activities & Nature of DRR Activities \\
\hline $\begin{array}{l}\text { National Youth Commission } \\
\text { (NYC) }\end{array}$ & $\begin{array}{l}1 \text { main office only, based in Quezon } \\
\text { City }\end{array}$ & $\begin{array}{l}\text { Ten Accomplished Youth } \\
\text { Organizations (TAYO) Awards in the } \\
\text { fourth quarter of the year }\end{array}$ & $\begin{array}{l}\text { Awarding of good practices in many } \\
\text { areas, including DRR }\end{array}$ \\
\hline Sangguniang Kabataan (SK) & One per village & $\begin{array}{l}\text { Youth Week in December, National Disaster } \\
\text { Consciousness Month (NDCM), and so on }\end{array}$ & Community-based DRR \\
\hline Red Cross Youth (RCY) & One per elementary and high school & National Volunteer Week in December & Disaster preparedness and response \\
\hline $\begin{array}{l}\text { Boy Scouts of the Philippines } \\
\text { (BSP) }\end{array}$ & $\begin{array}{l}116 \text { local councils nationwide } \\
(1.5 \text { million members in } 2010)\end{array}$ & Scouting Month in September & Disaster preparedness and response \\
\hline $\begin{array}{l}\text { Girl Scouts of the Philippines } \\
\text { (GSP) }\end{array}$ & 95 local councils nationwide & Girl Scouts Week in September & Disaster preparedness and response \\
\hline $\begin{array}{l}\text { Youth for the Environment in } \\
\text { Schools Organization (YES-O) }\end{array}$ & $\begin{array}{l}\text { One per elementary and high } \\
\text { school }\end{array}$ & YES Camp during summer & $\begin{array}{l}\text { DRR education related to the science } \\
\text { curriculum }\end{array}$ \\
\hline $\begin{array}{l}\text { Philippine Society of Youth } \\
\text { Science Clubs (PSYSC) }\end{array}$ & $\begin{array}{l}\text { At least one science club per } \\
\text { elementary and high school (however } \\
\text { only } 2,000 \text { clubs are affiliated with } \\
\text { PSYSC) }\end{array}$ & National Science Club Month in September & $\begin{array}{l}\text { DRR education related to the science } \\
\text { curriculum }\end{array}$ \\
\hline Student Councils & One per elementary and high school & $\begin{array}{l}\text { Varies depending on the priorities of the } \\
\text { student council }\end{array}$ & $\begin{array}{l}\text { Usually assigned to assist in } \\
\text { emergency drills }\end{array}$ \\
\hline
\end{tabular}


programs cater to their specific needs while delineating what role they will play in DRR (FEMA 2010). A variety of factors cause young people to be different from adults in terms of anatomical, physiological, psychological, and behavioral attributes (FEMA 2010). These differences become a key factor in determining what measures need to be undertaken to ensure young people's awareness, safety, and health. Ageappropriate programs specifically targeted to young people should be evaluated beforehand in order to ensure that they are suitable for the capacities and abilities of young people, so that potentially risky or dangerous activities can be avoided (FEMA 2010). In relation to young people aged below 18 years, experts warn that risks and responsibilities need to be weighed along with benefits of higher forms of participation (Shier 2001). It may also be true that full participatory roles and responsibilities are not feasible or necessary for every task or project (Head 2011). The facilitating adults should take the needed precautionary measures, in keeping with the culture of safety they are promoting.

\subsection{Getting Support from Adults}

Support from adults is important in order to make youth participation in DRR successful. According to the Children on the Frontline report (Walden, Hawrylyshyn, and Hall 2009), while young people are gaining DRR knowledge and skills, they do not have the supporting environment to put their knowledge and skills to good use by taking action. In a survey conducted by Fernandez (2012), the youth respondents put the least importance on the extent that age groups in the community mix and interlink, which helps explain why youth participation in the traditionally adult-dominated DRR activities is low. A review of SK accomplishments also revealed that the SK's performance is affected by the support, supervision, and assistance (or lack thereof) from adults in the local government and in NGOs, underscoring the need for greater support from adults, especially from barangay leaders who serve as role models for the youth (Balanon et al. 2007).

Adults need to come up with ways and means to strengthen and extend support to the youth to realize their enormous potential as effective partners in DRR. It is difficult to involve young people when they take action but lack resources for implementation (Checkoway 2011). In situations like this, adult allies are instrumental to youth participation (Walden, Hawrylyshyn, and Hall 2009; Checkoway 2011).

A number of civil society organizations have facilitated the DRR activities of some SKs. Examples would include the work done by Plan International in various locations throughout the country, coordinating with the SKs to engage the youth in increasing their knowledge about disasters as well as conducting practical DRR activities (Seballos and Tanner 2011; Candido 2013; San Francisco Municipal Government, n.d.); by YesPinoy Foundation in Rizal province, teaching the youth how to properly conduct earthquake drills in their barangay (Tahup 2011); by BALAY Rehabilitation Center, Center for Disaster Preparedness, and Save the Children (UK) in North Cotabato, helping the SK monitor the situation of children and work with the barangay (BALAY 2006). Upscaling the coverage of the work done by CSOs would allow more SKs to have access to capability-building resources that will enable them to conduct their own DRR activities.

\section{Conclusion}

The international principle of prioritizing the most vulnerable and ensuring their participation in disaster risk reduction has not been effectively realized with respect to the youth (Plan UK 2010). Young people are not given an active role in (or worse, are excluded from) the action toward disaster risk reduction. This review of national policies of the Philippines related to youth council participation in DRR shows discrepancies between ideal scenarios and actual youth participation in DRR in practice. So much more needs to be done in engaging young people in helping build disaster resilient communities. The youth in the Philippines constitute a fifth of the population and represent significant potentials to contribute to DRR efforts just by looking at one aspect, their massive number, although we must also caution against unrealistic expectations, given the historical level of participation in DRR that we have observed. Nevertheless, with the passage of the DRR and CCA laws and with the expected approval of the new Philippine Youth Development Plan, policies that explicitly encourage youth participation in DRR, we can expect more DRR initiatives involving young Filipinos in the near future, especially through the youth councils in each of the barangay in the country. Lessons from the experience of the Philippines in policy formulation and implementation related to youth participation in DRR can be useful for other countries in raising the involvement of their own young citizens toward a culture of safety and resilience.

\section{Acknowledgments}

We thank the Ministry of Education, Culture, Sports, Science, and Technology (MEXT) of Japan for the generous scholarship grant that made it possible for the first author to pursue his Master's and $\mathrm{PhD}$ degrees at Kyoto University. We also acknowledge the financial support for fieldwork from the Global Center of Excellence Program on Sustainability / Survivability Science for a Resilient Society Adaptable to Extreme Weather Conditions (GCOE-ARS) of Kyoto University.

\section{References}

Anderson, W. 2005. Bringing Children into Focus on the Social Science Disaster Research Agenda. International Journal of Mass Emergencies and Disasters 23 (3): 159-175.

Balanon, F. A., M. Ong, B. Torre, M. Puzon, J. P. Granada, and A. Trinidad. 2007. The Impact of Youth Participation in the Local Government Process: The Sangguniang Kabataan Experience. Makati, Philippines: United Nations Children's Fund. 
BALAY (BALAY Rehabilitation Center, Inc.). 2006. Integrating Children's Rights in Barangay Disaster Management and Development: A Trainor's Manual. Quezon City, Philippines: BALAY Rehabilitation Center,Inc. http://toolkit.ineesite.org/toolkit/INEEcms/uploads/1120/ Integrating_Childrens_Rights_Barangay.pdf.

Cadag, J. R., and J. C. Gaillard. 2012. Integrating Knowledge and Actions in Disaster Risk Reduction: The Contribution of Participatory Mapping. Area 44 (1): 100-109.

Candido, S. 2013. Plan International to Hold Climate Change Youth Camp. http://r08.pia.gov.ph/index.php?article=1251368171349.

Carey, J. 2011. Investing in Youth Policy. Asia-Pacific Interagency Group on Youth. http://www.investinginyouthpolicy.com/Investing In Youth Policy.pdf.

Checkoway, B. 1998. Involving Young People in Neighborhood Development. Children and Youth Services Review 20 (9-10): 765-795.

Checkoway, B. 2011. What Is Youth Participation? Children and Youth Services Review 33 (2): 340-345.

Checkoway, B., T. Allison, and C. Montoya. 2005. Youth Participation in Public Policy at the Municipal Level. Children and Youth Services Review 27 (10): 1149-1162.

CRED (Center for Research on the Epidemiology of Disasters). 2013. Disasters in Numbers. http://www.emdat.be/press-conference.

FEMA (Federal Emergency Management Agency - USA). 2010. Bringing Youth Preparedness Education to the Forefront: A Literature Review and Recommendations. http://www.fema.gov/media-librarydata/20130726-1859-25045-7593/get_informed_23_page_pdf_citizen prep review issue 6.pdf.

Fernandez, G. 2012. Youth Participation in Disaster Risk Reduction through Science Clubs in the Philippines. Unpublished Master's Thesis. Kyoto: Kyoto University.

Gaillard, J. C., and M. L. C. J. Pangilinan. 2010. Participatory Mapping for Raising Disaster Risk Awareness among the Youth. Journal of Contingencies and Crisis Management 18 (3): 175-179.

Galing Pook Foundation. 2007. A Community Prepared for Disasters. Infanta, Quezon. http://www.galingpook.org/awardees/2007/2007 outstanding infanta.htm

Head, B. 2011. Why Not Ask Them? Mapping and Promoting Youth Participation. Children and Youth Services Review 33 (4): 541-547.

IFRC (International Federation of Red Cross and Red Crescent Societies). 2009. Philippines: Plan 2009-2010. http://reliefweb.int/sites/ reliefweb.int/files/resources/2A6585B25807517C49257506002991 F4-Full Report.pdf.

Infanta Municipal Government. 2012. Infanta Forges Twinning Relationship with Makati City. http://infanta.gov.ph/?q=sisterhood.

Lyons, M., T. Schilderman, and C. Boano. 2010. Building Back Better: Delivering People-Centred Housing Reconstruction at Scale. Warwickshire, UK: Practical Action Publishing.

Makati SK Federation. 2013. Sangguniang Kabataan Memorandum 2013-005: Guidelines for the 2013 Annual Investment Plan.

Mitchell, T., K. Haynes, N. Hall, W. Choong, and K. Oven. 2008. The Roles of Children and Youth in Communicating Disaster Risk. Children, Youth and Environments 18 (1): 254-279.

Mitchell, T., T. Tanner, and K. Haynes. 2009. Children as Agents of Change for Disaster Risk Reduction: Lessons from El Salvador and the Philippines. Brighton, UK: Institute of Development Studies.

NDRRMC (National Disaster Risk Reduction and Management Council). 2010. Implementing Rules and Regulations of Republic Act No. 10121. http://www.ndrrmc.gov.ph/attachments/095 IRR.pdf.

NDRRMC (National Disaster Risk Reduction and Management Council). 2011. The National Disaster Risk Reduction and Management Plan (NDRRMP), 2011 to 2028. http://www.dilg.gov.ph/PDF_File/ resources/DILG-Resources-2012116-420ac59e31.pdf.

NSCB (National Statistical Coordination Board - Philippines). 2013. Poverty Incidence Unchanged, as of First Semester 2012. http://www. nscb.gov.ph/pressreleases/2013/PR-201304-NS1-04_poverty.asp.

NYC (National Youth Commission - Philippines). 2005. The Medium Term Youth Development Plan (MTYDP) 2005-2010. http://www. nyc.gov.ph/national-youth-commission-policy-development/pydpyaps.
NYC (National Youth Commission - Philippines). 2010. Highlights of the 2010 Youth Study: The Situation from the Perspective of the Youth. http://www.nyc.gov.ph/national-youth-commission-policydevelopment/national-youth-commission-resources.

NYC (National Youth Commission - Philippines). 2012. The Voice and Advocate of Youth - 2011 Accomplishment Report. http://www.nyc. gov.ph/national-youth-commission-reports.

Paunan, J. C. 2012. Hall of Famer Makati Wins "Gawad Kalasag” for Best Disaster Council in the Philippines. http://ncr.pia.gov.ph/index. php? article $=261350349870$.

Peek, L. 2008. Children and Disasters: Understanding Vulnerability, Developing Capacities, and Promoting Resilience - An Introduction. Children, Youth and Environments 18 (1):1-29.

Pelling, M. 2007. Learning from Others: The Scope and Challenges for Participatory Disaster Risk Assessment. Disasters 31 (4): 373-385.

Plan UK. 2010. Child-Centred Disaster Risk Reduction: Building Resilience through Participation. London: Plan UK.

San Francisco Municipal Government. n.d. San Francisco and Plan Initiatives versus 10 Point Essentials. http://unisdr-apps.net/confluence/ download/attachments/9994301/San+Francisco+and+Plan+initiativ es+versus+10+Point+Essentials_draft+1.pdf.

Shier, H. 2001. Pathways to Participation: Openings, Opportunities and Obligations. Children \& Society 15 (2): 107-117.

Seballos, F., and T. Tanner. 2011. Enabling Child-Centred Agency in Disaster Risk Reduction. http://www.preventionweb.net/english/ hyogo/gar/2011/en/bgdocs/Seballos_\&_Tanner_2011.pdf.

Shaw, R., Y. Takeuchi, K. Shiwaku, $\bar{Q}$. Gwee, G. Fernandez, and B. Yang. 2009. 1-2-3 of Disaster Education. Kyoto: Kyoto University.

SPW (Students Partnership Worldwide) and DFID (Department for International Development - UK). 2010. Youth Participation in Development: A Guide for Development Agencies and Policy Makers. London: DFID-CSO Youth Working Group.

Strietska-Ilina, O., C. Hofmann, M. D. Haro, and S. Jeon. 2011. Skills for Green Jobs: A Global View: Synthesis Report Based on 21 Country Studies. Geneva, Switzerland: International Labour Office.

Tahup, U. 2011. Disaster Preparedness Drill, Training Conducted for Cainta Youth Leaders. http://www.ugnayan.com/ph/Rizal/Cainta/ article/GYP.

Timmerman, G. 2009. Youth Policy and Participation: An Analysis of Pedagogical Ideals in Municipal Youth Policy in the Netherlands. Children and Youth Services Review 31 (5): 572-576.

Twigg, J. 2009. Identifying Partnership Needs and Opportunities. Disaster Studies Working Paper 18. London: Aon Benfield UCL Hazard Research Centre.

Ubac, M. L. 2012. UN Lauds Philippines' Climate Change Laws "World's Best". http://globalnation.inquirer.net/35695/un-laudsphilippines $\%$ E2\%80\%99-climate-change-laws- $\%$ E2\%80\%98world $\%$ E2\%80\%99s-best $\%$ E2\%80\%99.

UN (United Nations). 2010a. World Program of Action for Youth. New York: UN.

UN (United Nations). 2010b. World Youth Report: Youth and Climate Change. New York: UN.

UNICEF EAPRO (United Nations Children's Fund East Asia and the Pacific Regional Office). 2008. Young People's Civic Engagement in East Asia and the Pacific. http://www.unicef.org/adolescence/ cypguide/files/EAPRO_study_by_Innovations_in_Civic_Participation. pdf.

UNISDR (United Nations International Strategy for Disaster Reduction). 2000. United Nations 2000 World Disaster Reduction Campaign to Focus on Disaster Prevention, Education and Youth. http://www.unisdr.org/2000/campaign/pa-camp00-kit-eng.htm.

UNISDR (United Nations International Strategy for Disaster Reduction). 2005. Hyogo Framework for Action 2005-2015: Building the Resilience of Nations and Communities to Disasters. http://www. unisdr.org/2005/wcdr/intergover/official-doc/L-docs/Hyogoframework-for-action-english.pdf.

Walden, D., K. Hawrylyshyn, and N. Hall. 2009. Children on the Frontline: Children and Young People in Disaster Risk Reduction. London: Plan International,World Vision.

Open Access This article is distributed under the terms of the Creative Commons Attribution License which permits any use, distribution, and reproduction in any medium, provided the original author(s) and source are credited. 